\title{
Soft Tissue Response
}

National Cancer Institute

\section{Source}

National Cancer Institute. Soft Tissue Response. NCI Thesaurus. Code C132457.

An evaluation of the soft tissue response of the disease to the therapy. 